\title{
Spatiotemporal Variation and Risk Assessment of Pesticides in Water of the Lower Catchment Basin of Acheloos River, Western Greece
}

\author{
Nikolaos Stamatis, ${ }^{1,2}$ Dimitra Hela, ${ }^{3}$ Vassilios Triantafyllidis, ${ }^{3}$ and Ioannis Konstantinou ${ }^{1}$ \\ ${ }^{1}$ Department of Environmental and Natural Resources Management, University of Patras, Seferi 2, 30100 Agrinio, Greece \\ ${ }^{2}$ Department of Aquaculture and Fisheries, Faculty of Agricultural Technology, Technological Education Institute of Messolonghi, \\ 30200 Messolonghi, Greece \\ ${ }^{3}$ Department of Agricultural Enterprise and Food Management, University of Patras, Seferi 2, 30100 Agrinio, Greece
}

Correspondence should be addressed to Ioannis Konstantinou; iokonst@upatras.gr

Received 31 August 2013; Accepted 7 October 2013

Academic Editors: K. Boltes and A. Hursthouse

Copyright (c) 2013 Nikolaos Stamatis et al. This is an open access article distributed under the Creative Commons Attribution License, which permits unrestricted use, distribution, and reproduction in any medium, provided the original work is properly cited.

\begin{abstract}
A three-year monitoring survey (March 2005-February 2008) was conducted to investigate, on monthly basis, the presence of thirty pesticides belonging to various categories and metabolites, in Acheloos River (Western Greece), one of the most important water resources in Greece. Six sampling stations along the river were established. Water analyses were performed using solid-phase extraction combined with gas chromatography with flame thermionic detector and mass spectrometry. Statistical analysis using one-way ANOVA and Duncan's multiple range test $(P<0.05)$ was used to compare annual mean concentrations of pesticides, seasonal and spatial distribution. In general, the highest mean concentrations of the pesticides were recorded at the three stations downstream. The greatest average concentrations were determined during spring and summer in agreement with the pesticide application period. The observed lower concentrations after 2006 reflect the land-use change because of the elimination of tobacco, the main cultivation of the area for many decades. The compounds most frequently detected were diazinon (78.6\%), DEA (69.3\%), and fenthion (52.6\%). Environmental risk assessment using risk quotient (RQ) approach showed high risk for six insecticides in 2005 and one in 2007. A compliance with the European Environmental Quality Standards (EQS) was observed for the priority pesticides.
\end{abstract}

\section{Introduction}

The occurrence of pesticides and their conversion products in aquatic systems is one of the major environmental problems worldwide. Their widespread use combined with overapplication, accidental spills, runoff from cultivated areas, and faulty waste disposal creates environmental pollution concerns [1]. During the last three decades, pesticide usage for agricultural and nonagricultural purposes has increased dramatically and has resulted in the presence of their residues in various environmental matrices. Although there are many significant practices to manage point-source pollution, very little progress has been achieved in facing nonpoint source pollution, especially of surface waters, due to seasonal variations, inherent problems, and multiplicity of the processes
[2]. Surface runoff is the main way for pesticides moving from agricultural fields to surface waters [3]. Several factors, such as the topography and the weather of the studying area, soil characteristics, agricultural practices, and chemical and environmental properties of individual pesticides, play the major roles for the amount of pesticides lost from fields and transported to aquatic environment [4]. The temporal and spatial distribution of pesticide concentrations depends on all these factors, but it is difficult to be predicted [5].

In recent years, analytical methods based on solidphase extraction (SPE), solid-phase microextraction (SPME), and liquid-phase microextraction (LPME) have been used. These techniques are inexpensive, as they require common laboratory equipment and very small amounts of organic solvents. Besides, they offer the advantages of simplicity, 
shorter analysis time, and less interferences. Solid-phase extraction has been widely used as an alternative method for the isolation and the preconcentration of many organic compounds, including pesticides, and has been extensively applied to the extraction of such pollutants from water samples $[2,6,7]$.

The great majority of extraction techniques for pesticides are followed by gas chromatography (GC) or high performance liquid chromatography (HPLC) because of the complexity of the matrices and the low concentrations of pesticides in natural water samples (usually ng $\mathrm{L}^{-1}$ ). HPLC methods are more suitable for determining thermally labile and polar pesticides. Both chromatographic techniques methods are very efficient for determining environmental pesticide residues with high resolution and sensitivity using specific detectors or coupled with mass spectrometry.

The determination of pesticides in water samples, such as river, lake, and sea water, is necessary in order to verify whether inadmissible levels are present. In the last decade, emphasis has been given to pesticides with higher polarity and lower persistence. Due to their enhanced solubility, modern pesticides are able to reach the surface water through agricultural runoff and leaching to ground water [8]. Numerous studies have revealed the widespread occurrence of pesticides in European and American fresh surface waters and ground waters [9].

Pesticide residues have been detected also in surface water, ground water, and drinking water samples across Greece indicating that some major water resources are contaminated [9]. These detections are the result of extensive regional and nationwide studies often using analysis at very high sensitivity. According to the occurrence and concentration range of pesticides detected in rivers in Greece, two main groups can be divided. The first one includes pesticides that are occasionally detected sharing one or more of the following characteristics: low application rates, usage in limited geographical areas, short soil lifetimes, short aquatic lifetimes, and lower run-off hazard. The other group consists of the compounds that are found frequently in Greek surface waters and represent seasonally increased concentrations (i.e., atrazine, alachlor, and diazinon). Characteristic properties of the above compounds are: higher application rates, widespread usage, higher hazard due to runoff, and longer aquatic half-lives [9].

The data available in running literature concerning river water pollution by pesticides in Greece regard a number of principal rivers that are draining mainly agricultural areas. Most studies on pesticide monitoring of Greek freshwater resources have been summarized in a previously published review by the authors [9]. Most of the major Greek rivers like Aliakmon [10], Loudias [11], Axios [12], Pinios [13], Kalamas [14], Mornos [15], and Evrotas [16] and major lakes like Trichonida [13], Marathonas [16], Pamvotida [14], Volvi, Vistonida, and Prespa [17] have been monitored for pesticide residues. In addition, the existing information covers the last two decades but only few systematic monitoring studies that include several pesticide categories have been published for rivers such as Aliakmon, Axios, Loudias, Louros, Arachthos, and Kalamas. However, no information was available for the pesticide contamination of the River Acheloos, one of the most important Greek rivers; although that studies on physicochemical parameters, nutrients, organic carbon and other hazardous compounds like metals and hydrocarbons have been reported [18-21].

This work presents for the first time a seasonal and spatial study on the variation and distribution of pesticides in the water of Acheloos River for a three-year monitoring period (2005-2008). Solid-phase extraction followed by gas chromatography with flame thermionic detector (FTD) and mass spectrometry (MS) were applied for the screening of thirty pesticides and metabolites. Statistical analysis of the results was performed in order to investigate significant differences in pesticide concentration among years, seasons, and sampling sites. An important objective of the study was also to evaluate the effect of land-use changes after the considerable reduction of tobacco, which was the main cultivation of the region for a long period in the past. In addition, the point source of pesticide pollution resulting from the outflow of wastewater treatment plant (WWTP) of Agrinio was investigated. Finally, the risk assessment and compliance with the established environmental quality standards according to the Water Framework Directive (2000/60/EC) are discussed.

\section{Experimental}

2.1. Area Description and Sampling Site. Acheloos River, located in the southwestern part of the country, is one of the most important rivers in Greece, the first in water contribution, and the second in length, found in the Greek territory. The river springs from Pindos Mountains at an altitude of $1,700 \mathrm{~m}$ and crosses a distance of $235 \mathrm{~km}$ before it meets the Ionian Sea. Its yearly outflow is estimated to be $7.8 \cdot 10^{9} \mathrm{~m}^{3}$. The average precipitation in the basin is approximately $1,380 \mathrm{~mm} /$ year. The rainy season lasts from November till February and driest months are July and August. The drainage basin of Acheloos covers a total area of $6329 \mathrm{~km}^{2}$ and includes three major subcatchments, the upper part $\left(1100 \mathrm{~km}^{2}\right)$, the middle part $\left(3250 \mathrm{~km}^{2}\right)$, and the lower part $\left(1979 \mathrm{~km}^{2}\right)$ of the basin. The shape of its basin is oblong with a maximum axis of $147 \mathrm{~km}$ length and $63 \mathrm{~km}$ width. The upper part of the basin has major tributaries such as Karpenisiotis, Trikeriotis, and Agrafiotis rivers and includes mountainous terrain (mean catchment altitude $840 \mathrm{~m}$ ). In the middle subcatchment four large hydroelectric dams and an irrigation dam (Tavropos, Kremasta, Kastraki, and Stratos) that form artificial lakes are situated. Detailed morphometric characteristics of the Acheloos reservoirs are published elsewhere [18]. The lower part includes the Trichonida, Lysimachia, Amvrakia, and Ozeros natural lakes, the allouvial plain and the Messolonghi, Etoliko, and Klisova lagoons [18]. The delta plain, which covers an area of $300 \mathrm{~km}^{2}$ [22] consists of a large network of irrigation channels.

The Acheloos estuary is of high environmental importance as it affects the distributions of nutrients in the entire Northwestern section of Patraikos Gulf and in the nearshore part of the Ionian Sea [20]. In addition, the ecological 


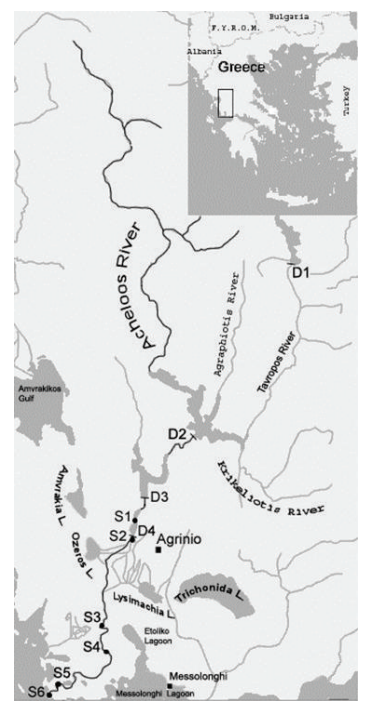

Figure 1: Map of the six sampling sites: $S_{1}$ : bridge at village Matsouki, $\mathrm{S}_{2}$ : after the dam of Stratos, $\mathrm{S}_{3}$ : after the outflow of WWTP of Agrinio, $\mathrm{S}_{4}$ : bridge between villages Neochori and Katochi, $S_{5}: 5 \mathrm{~km}$ before the river mouth, $S_{6}$ : the river mouth, and four hydroelectric dams $\left(\mathrm{D}_{1}\right.$ : Tavropos, $\mathrm{D}_{2}$ : Kremasta, $\mathrm{D}_{3}$ : Kastraki, and $\mathrm{D}_{4}$ : Stratos).

importance of the estuary is high as it is connected to coastal lagoons which are under the protection of the Ramsar convention. Finally, the delta plain belongs to the Natura 2000 sites.

The Acheloos River water is used in the agriculture and the generation of electricity. The watershed is not industrialized and agriculture contributes about $45 \%$ of the average income for the region. Acheloos River receives the land washout and runoff of a relatively large cultivated area situated mostly in the middle and lower part of its basin causing serious nonpoint source pollution. In particular in the lower part of the river delta agricultural land covers $41 \%$ of the area [18].

The monitoring of the present study is focused on the middle and lower part of the river basin while the upper part is excluded due to the mountainous relief and the absence of significant agricultural activity. $\mathrm{Six}\left(\mathrm{S}_{1}-\mathrm{S}_{6}\right)$ stations were sampled along the main flow and estuary of the river (Figure 1). The selected sampling stations are representative of the major freshwater inputs into the river and, as such, represent possible sources of pesticide discharge into the river: the bridge at village Matsouki $\left(S_{1}\right)$, the site after the dam of Stratos $\left(\mathrm{S}_{2}\right)$, after the discharge of WWTP of Agrinio city $\left(\mathrm{S}_{3}\right)$, the bridge between villages Neochori and Katochi $\left(\mathrm{S}_{4}\right), 5 \mathrm{~km}$ before the river mouth $\left(\mathrm{S}_{5}\right)$, and at the river mouth $\left(S_{6}\right)$. Dams affect the flow of Acheloos River more than the seasonal rainfall (Figure 1). Due to loss of water that occurs along river's flow in the wide irrigation network at the lower part of the basin, the basic maintenance flow in the estuaries was reported to vary from a mean monthly flow of 17.8 (July) to $34.7 \mathrm{~m}^{3} \mathrm{~s}^{-1}$ (January) [23]. Composite hydrographs for the mean monthly discharge of Acheloos, upstream and downstream of the reservoirs, for 22-year time series (19801999) are reported elsewhere [18]. Finally, Acheloos River receives the treated effluents of the wastewater treatment plant (WWTP) of Agrinio city, the larger urban center in the area. Details on the description of WWTP can be found elsewhere $[24,25]$.

2.2. Chemicals. All pesticide standards (purity $>98 \%$ ) were purchased from Riedel-de-Haën (Seelze, Germany). All solvents used (acetone, LC-grade water, ethyl acetate, and methanol) were pesticide residue analysis grade from Merck (Darmstadt, Germany). Primary stock standard solutions of the target pesticides were prepared individually in methanol at a concentration of $200 \mathrm{ng} / \mathrm{mL}$ and stored at $-18^{\circ} \mathrm{C}$. The working solutions of the mixtures at various concentrations were prepared by appropriate dilution of the stock solutions and were stored at $4^{\circ} \mathrm{C}$ in the dark. Calibration standards were renewed every week. Oasis HLB (divinylbenzene/Nvinylpyrrolidone copolymer) cartridges (200 mg, $6 \mathrm{~mL}$ ) from Waters (Mildford, MA, USA) were used for water samples extraction.

2.3. Water Sampling. Water samples $(2.5 \mathrm{~L})$ were taken using polypropylene water samplers (Windaus-Labortechnik) at a depth of $1 \mathrm{~m}$ below the water surface. Water samples were collected monthly between March 2005 and February 2008. They were collected in precleaned amber glass bottles and transported to the laboratory under cool conditions. Upon arrival to the laboratory within $6 \mathrm{~h}$ of collection, the samples were filtered through filter paper (Whatman, USA) to eliminate particulate matter and other suspended solid matter and then stored in the dark at $4^{\circ} \mathrm{C}$ in a cold room. Further extraction of the samples was carried out within $24 \mathrm{~h}$ of collection to keep microbial degradation to a minimum. The target analytes included thirty pesticides and metabolites selected on the basis that they have been previously reported in environmental surface waters of Greece and other European countries and on data for the agricultural application in the basin. Seven of them belong to the priority pollutants of Annex I, Directive 2008/105/EC.

2.4. Sample Extraction and Chromatographic Analyses. The extraction and sample preparation of the water samples are based on offline solid-phase extraction (SPE). SPE was performed using a 12-fold vacuum extraction box (Visiprep, Supelco, Bellefonte, PA, USA) fitted on a pump to achieve the appropriate vacuum for the solid phase extraction. Prior to the extraction water samples were allowed to reach room temperature. The SPE cartridges (Oasis HLB) were conditioned with $5 \mathrm{~mL}$ of ethyl acetate, $5 \mathrm{~mL}$ methanol, and $5 \mathrm{~mL}$ LC-grade water at a flow rate of $1 \mathrm{~mL} \mathrm{~min}^{-1}$. Then, water samples were added at a flow rate of $10 \mathrm{~mL} \mathrm{~min}^{-1}$ and finally the cartridges were washed with $6 \mathrm{~mL}$ grade water. The cartridges were dried by nitrogen stream for 20 minutes. After sample extraction, the pesticides trapped in the cartridge were collected by using $2 \times 5 \mathrm{~mL}$ of ethyl acetate as eluting solvent at $1 \mathrm{~mL} \mathrm{~min}^{-1}$. Small quantities of anhydrous $\mathrm{Na}_{2} \mathrm{SO}_{4}$ were added to remove any water content in the sample. The eluate was concentrated to a final volume of $0.2 \mathrm{~mL}$ in a gentle stream of nitrogen. 
A Shimadzu 17A capillary gas chromatograph equipped with flame thermionic detector (FTD) and Equity-1 column (30 m, $0.25 \mathrm{~mm}$ I.D., $0.25 \mu \mathrm{m}$ ) containing dimethylpolysiloxane was used. The column was programmed from $55^{\circ} \mathrm{C}$ $(2 \mathrm{~min})$ to $160^{\circ} \mathrm{C}(10 \mathrm{~min})$ at $5^{\circ} \mathrm{C} \mathrm{min}^{-1}$, to $210^{\circ} \mathrm{C}(20 \mathrm{~min})$ at $5^{\circ} \mathrm{C} \mathrm{min}^{-1}$, and to $270^{\circ} \mathrm{C}(2 \mathrm{~min})$ at $20^{\circ} \mathrm{C} \mathrm{min}^{-1}$. Helium was used as carrier $\left(1.5 \mathrm{~mL} \mathrm{~min}^{-1}\right)$ and make-up gases (40 $\mathrm{mL} / \mathrm{min})$, respectively. The detector gases were hydrogen and air at flows of 4 and $120 \mathrm{~mL} \mathrm{~min}^{-1}$, respectively. The detector temperature was set to $290^{\circ} \mathrm{C}$ and the injector temperature to $220^{\circ} \mathrm{C}$. An alkali metallic salt $\left(\mathrm{Rb}_{2} \mathrm{SO}_{4}\right)$ bonded to a $0.2 \mathrm{~mm}$ spiral of platinum wire generated the ions. The splitless mode was used with the valve opened after $60 \mathrm{~s}$. The injection volume was $2 \mu \mathrm{L}$. Quantification of pesticides was performed using the internal standard (fenitrothion) method based on peak areas.

Secondary confirmation was performed using a GCMS, QP-2010 Shimadzu equipped with a soft polar capillary column SPB $5 \mathrm{~ms}(30 \mathrm{~m}, 0.25 \mathrm{~mm}, 0.25 \mu \mathrm{m})$, containing $5 \%$ phenylpolysiloxane and 95\% dimethyl-polysiloxane, used at the following chromatographic conditions: injector temperature $220^{\circ} \mathrm{C}$, column program of temperatures $55^{\circ} \mathrm{C}(2 \mathrm{~min})$ to $154^{\circ} \mathrm{C}(3 \mathrm{~min})$ at $3^{\circ} \mathrm{C} \mathrm{min}^{-1}$, to $160^{\circ} \mathrm{C}(7 \mathrm{~min})$ at $1^{\circ} \mathrm{C} \mathrm{min}{ }^{-1}$, to $210^{\circ} \mathrm{C}(4 \mathrm{~min})$ at $5^{\circ} \mathrm{C} \mathrm{min}{ }^{-1}$, and to $270^{\circ} \mathrm{C}(2 \mathrm{~min})$ at $20^{\circ} \mathrm{C} \mathrm{min}^{-1}$. Helium was used as the carrier gas at $67.3 \mathrm{KPa}$. The ion source and transfer line were kept at $200^{\circ} \mathrm{C}$ and $310^{\circ} \mathrm{C}$, respectively. The quadrupole mass spectrometer was operated in electron impact (EI) ionization mode at $70 \mathrm{eV}$ and monitored ions from $\mathrm{m} / z 50$ to 450 . The splitless mode was used for injection of $2 \mu \mathrm{L}$ volume, with the valve opened for $30 \mathrm{~s}$. Characteristic ions of the selected pesticides $[25,26]$ were chosen for screening analysis in selected ion monitoring (SIM) mode.

2.5. Quality Control and Treatment of Data. Validation studies of the method were performed using river water. The recovery studies were carried out by spiking three replicates of river samples at the concentration level of $0.1 \mu \mathrm{g} \mathrm{L}^{-1}$. For each pesticide studied the mean recovery value ranged between 70 and $120 \%$ while the relative standard deviation was less than $15 \%[25,26]$. The precision of the method, determined as relative standard deviation (RSD), was obtained from the repeated analysis $(n=5)$ of spiked extracts during the same day (repeatability) and in different days (reproducibility). Repeatability of the method was considered satisfactory with standard deviations from 5 to $16 \%$. The limits of detection (LODs) were determined experimentally from the injection of spiked river samples and calculated using a signal-to-noise ratio $(S / N)=3$. Low LODs were achieved ranging from $2 \mathrm{ng} \mathrm{L}^{-1}$ to $15 \mathrm{ng} \mathrm{L}^{-1}$ in water samples $[25,26]$. The confirmation criteria applied to the target pesticides in the wastewater samples were presence of the three characteristic fragment ions (Table 1) at the correct retention time $( \pm 0.05)$ and with the correct relative ion intensity $( \pm 30 \%)$.

The results obtained by the three-year monitoring of Acheloos River were statistically analyzed. Values were compared
TABLE 1: Mean, minimum, and maximum concentrations $\left(\mathrm{ng} \mathrm{L}^{-1}\right)$ and frequency of detection (\%) for the nineteen most frequently detected pesticides and metabolites.

\begin{tabular}{|c|c|c|c|c|}
\hline \multirow{2}{*}{ Pesticides } & \multicolumn{3}{|c|}{ Concentration $\left(\mathrm{ng} \mathrm{L}^{-1}\right)$} & \multirow{2}{*}{$\%$ detection } \\
\hline & Mean & Min & Max & \\
\hline \multicolumn{5}{|c|}{ Insecticides } \\
\hline Diazinon & 19.0 & $<\mathrm{LOD}$ & 70.3 & 78.6 \\
\hline Fenthion & 11.1 & $<$ LOD & 84.1 & 52.6 \\
\hline Methidathion & 4.5 & $<\mathrm{LOD}$ & 26.7 & 42.2 \\
\hline Pirimiphos methyl & 12.4 & $<\mathrm{LOD}$ & 83.5 & 40.1 \\
\hline Dichlorvos & 8.0 & $<\mathrm{LOD}$ & 66.4 & 39.1 \\
\hline Malaoxon & 5.5 & $<\mathrm{LOD}$ & 80.6 & 35.4 \\
\hline Chlorpyrifos & 12.2 & $<\mathrm{LOD}$ & 101.2 & 31.8 \\
\hline Chlorpyrifos methyl & 7.1 & $<$ LOD & 77.1 & 31.3 \\
\hline Parathion methyl & 6.5 & $<\mathrm{LOD}$ & 66.2 & 29.7 \\
\hline Dimethoate & 3.0 & $<\mathrm{LOD}$ & 45.1 & 21.4 \\
\hline \multicolumn{5}{|c|}{ Herbicides } \\
\hline Atrazine desethyl & 56.1 & $<\mathrm{LOD}$ & 316.9 & 69.3 \\
\hline Atrazine & 18.4 & $<\mathrm{LOD}$ & 288.3 & 42.7 \\
\hline Alachlor & 18.7 & $<\mathrm{LOD}$ & 213.5 & 50.0 \\
\hline Trifluralin & 14.3 & $<\mathrm{LOD}$ & 237.0 & 28.1 \\
\hline S-Metolachlor & 2.0 & $<\mathrm{LOD}$ & 20.5 & 24.5 \\
\hline \multicolumn{5}{|c|}{ Fungicides } \\
\hline Penconazole & 21.2 & $<\mathrm{LOD}$ & 227.1 & 43.2 \\
\hline Cyproconazole & 51.1 & $<\mathrm{LOD}$ & 724.1 & 31.8 \\
\hline Triadimefon & 10.8 & $<\mathrm{LOD}$ & 192.3 & 40.1 \\
\hline Pyrazophos & 1.4 & $<\mathrm{LOD}$ & 32.7 & 17.2 \\
\hline
\end{tabular}

by one-way ANOVA test and mean differences were determined using Duncan's test $(P<0.05)$. In cases that the sample concentrations were below the LOD, a concentration equal to half of the detection limit was used for the calculations. The data were analyzed using the SPSS 15.0 program for Windows.

2.6. Calculation of PNECs and Risk Assessment. The environmental risk posed by the studied pesticides on Acheloos River ecosystem was assessed through the calculation of risk quotients (RQ) as described previously [27]. RQ values for aquatic organisms were calculated from the measured environmental concentration (MEC) and the predicted no effect concentration (PNEC) of the pesticides (RQ = MEC/PNEC). In order to overcome the uncertainty of this conservative assessment associated with the accuracy, inherent variability, model errors, and lack of data in the determination of toxicity values, PNEC values were calculated by dividing the lowest long-term NOEC or short-term L(E)C50 (lethal/effect) when NOEC values are lacking, for the most sensitive species by the appropriate assessment factors (AFs) for three trophic levels (fish, zooplankton, and phytoplankton) according to the European Technical Guidance Document [27-29]. The assessment factor can vary depending on the organisms being assessed and whether the toxicity endpoint is acute, based on short-term, lethal, or immobility effects (LC/EC50) or 
chronic, based on no observed effect (NOEC). According to TGD guidelines [27], an assessment factor of 1000 was used in the cases that at least one short-term assay at one trophic level was available, an assessment factor of 100 was used when data from one long-term assay with either fish or zooplankton were available, and finally assessment factors of 50 and 10 were used in the cases of two and three existing long-term assays, respectively. Ecotoxicological data (Table 6) were obtained from FOOTPRINT pesticide properties database [30], PAN Pesticides Database [31] and other studies containing toxicological data [32]. RQ for each pesticide was calculated using the worst-case scenario; that is, the maximum MEC was used. A commonly used risk ranking criteria were applied: $\mathrm{RQ}<0.1$ means minimal risk, $0.1 \leq \mathrm{RQ}<1$ means median risk, and $\mathrm{RQ} \geq 1$ means high risk [33].

\section{Results and Discussion}

3.1. Occurrence and Spatiotemporal Variation of Pesticides. Thirty pesticides and metabolites were analyzed in the water samples of Acheloos River. Ten of them were sporadically detected (carbofuran, simazine, pyrimethanil, quinalphos, fenthion sulfoxide, triazophos, azinphos methyl, phosalone, pirimiphos methyl, and tebuconazole); therefore they were not statistically studied. Four herbicides (alachlor, atrazine, S-metolachlor, trifluralin), one metabolite (desethyl atrazine, DEA), nine insecticides (chlorpyrifos, chlorpyrifos methyl, diazinon, dichlorvos, dimethoate, fenthion, methidathion, parathion methyl and pirimiphos methyl), one metabolite (malaoxon), and four fungicides (cyproconazole, penconazole, pyrazophos, and triadimefon), were detected in the water samples during the monitoring period of three years: 2005, 2006, and 2007.

Table 1 presents mean, minimum, and maximum concentrations and the percentage frequency of detections of the nineteen selected pesticides for the period 2005-2007 and all stations. The highest frequency of detection was observed for diazinon (78.6\%), alachlor (50\%), penconazole (43.2\%), and DEA (69.3\%) for insecticides, herbicides, fungicides, and metabolites, respectively. The above pesticides combine two or more of the following properties: widespread use, high soil and aquatic half-lives, and run-off hazard. They were used in past and recent years in various cultivations in the lower part of Acheloos basin such as corn, olive trees, tobacco, cereals and vegetables. Low detection frequencies were observed for eight pesticides (chlorpyrifos $31.8 \%$, cyproconazole $31.8 \%$, chlorpyrifos methyl $31.3 \%$, parathion methyl $29.7 \%$, trifluralin $28.1 \%$, S-metolachlor $24.5 \%$, dimethoate $21.4 \%$, and pyrazophos $17.2 \%)$. These pesticides have one or more of the following properties: small scale use, short soil and aquatic lifetimes, and low run-off hazard. The spatiotemporal variation of the most frequently detected compounds for each pesticide category is presented in Figures 2, 3, and 4.

3.1.1. Spatial Distribution. A general trend for the three categories (herbicides, insecticides, and fungicides) of target compounds was observed in annual average concentrations for the selected sampling stations. Greater values were recorded for the last three stations $\left(S_{4}, S_{5}\right.$, and $\left.S_{6}\right)$ than those for the stations upstream $\left(S_{1}, S_{2}\right.$, and $\left.S_{3}\right)$. However, nonsignificant differences were observed for thirteen of the compounds (Table 2). This reflects the present and past widespread uses of the compounds in most of the cultivations in the lowest Acheloos basin agricultural area (i.e., olives, corn, cotton, alfalfa, citrus, asparagus, vegetable, rice, and grapes). In addition, significantly different mean annual concentrations along stations were observed for pesticides such as chlorpyrifos, fenthion, diazinon, and dichlorvos.

The spatial distribution of annual means for herbicides showed maximum concentrations for atrazine $\left(\mathrm{S}_{4}: 70.9 \pm\right.$ $\left.29.8 \mathrm{ng} \mathrm{L}^{-1}\right)$ and its metabolite DEA $\left(\mathrm{S}_{4}: 91.1 \pm 48.2 \mathrm{ng} \mathrm{L}^{-1}\right)$ in 2005 , trifluralin $\left(\mathrm{S}_{6}: 34.8 \pm 24.8 \mathrm{ng} \mathrm{L}^{-1}\right)$ and DEA $\left(\mathrm{S}_{3}\right.$ : $\left.44.8 \pm 23.0 \mathrm{ng} \mathrm{L}^{-1}\right)$ in 2006 , and alachlor $\left(\mathrm{S}_{5}: 20.9 \pm 9.51 \mathrm{ng} \mathrm{L}^{-1}\right)$ and DEA $\left(S_{1}: 212 \pm 90.7 \mathrm{ng} \mathrm{L}^{-1}\right)$ in 2007. In the case of fungicides, the highest mean concentrations were detected for penconazole $\left(\mathrm{S}_{5}: 65.2 \pm 26.9 \mathrm{ng} \mathrm{L}^{-1}\right)$ in 2005 , for cyproconazole $\left(\mathrm{S}_{5}: 235 \pm 84.6 \mathrm{ng} \mathrm{L}^{-1}\right)$ in 2006 , for penconazole $\left(\mathrm{S}_{3}\right.$ : $\left.47.3 \pm 17.6 \mathrm{ng} \mathrm{L}^{-1}\right)$ and cyproconazole $\left(\mathrm{S}_{4}: 44.4 \pm 27.78 \mathrm{ng} \mathrm{L}^{-1}\right)$ in 2007. Annual mean concentrations of fungicides showed an increasing trend after sampling station $\mathrm{S}_{3}$ which is situated after the effluent of wastewater treatment plant of Agrinio city for each separate year of sampling period. According to the results published elsewhere [25] penconazole and cyproconazole were detected in effluent samples at concentration range between $<$ LOD and $45.08 \mathrm{ng} \mathrm{L}^{-1}$ and $<\mathrm{LOD}$ and $349.4 \mathrm{ng} \mathrm{L}^{-1}$, respectively. The presence of azoles in water samples of Acheloos River comes from agricultural applications in the surrounding area as well as from uses for pest control in the city and also from nonagricultural sources (biocidal products used for preservation of wood and coatings). Insecticides appeared with lower concentrations in comparison with herbicides and fungicides in each sampling point, respectively. The maximum mean concentration in 2005 was detected for chlorpyrifos at $\mathrm{S}_{6}\left(81.79 \pm 20.4 \mathrm{ng} \mathrm{L}^{-1}\right)$, in 2006 for pirimiphos methyl at $\mathrm{S}_{2}\left(30.03 \pm 19.7 \mathrm{ng} \mathrm{L}^{-1}\right)$, and in 2007 for diazinon at $\mathrm{S}_{5}\left(45.35 \pm 5.3 \mathrm{ng} \mathrm{L}^{-1}\right)$. The different method of application among pesticide categories may have resulted in the lower levels of residual concentrations recorded in the case of insecticides.

As it can be seen in Table 2, the three-year mean concentrations along sampling stations show similar trend to annual average concentrations described above for the different pesticide groups. In the case of herbicides, the maximum three-year mean concentration was recorded for DEA (46.6-69.4 $\mathrm{ng} \mathrm{L}^{-1}$ ) and the minimum for S-metolachlor $\left(1.70-3.67 \mathrm{ng} \mathrm{L}^{-1}\right)$, while there is no evidence by statistical analysis of significant differences among sampling stations for any of the target compounds. The same observation stands for fungicides with the highest three-year mean concentrations recorded for cyproconazole (14.4-92 ng/L) and the lowest for pyrazophos (1.52-3.41 ng L $\left.\mathrm{L}^{-1}\right)$.

On the other hand, five of the nine detected insecticides (dichlorvos, parathion methyl, chlorpyrifos, diazinon, and fenthion) and the metabolite malaoxon had three-year mean 


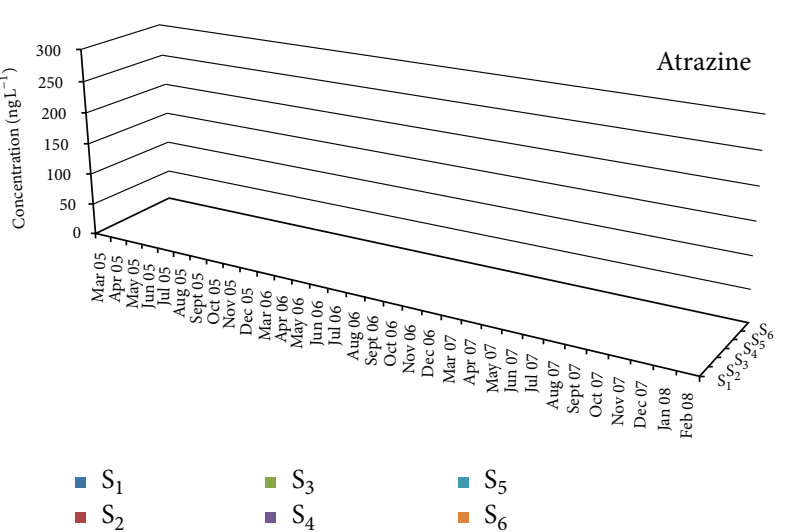

(a)

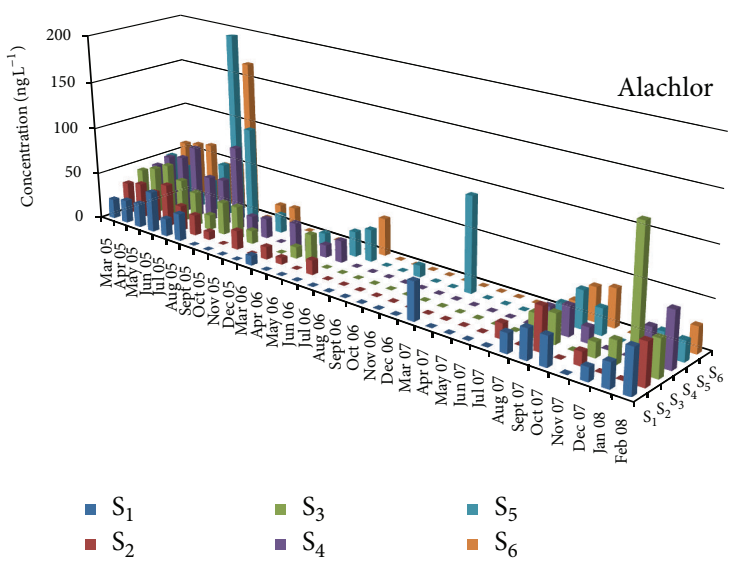

(b)

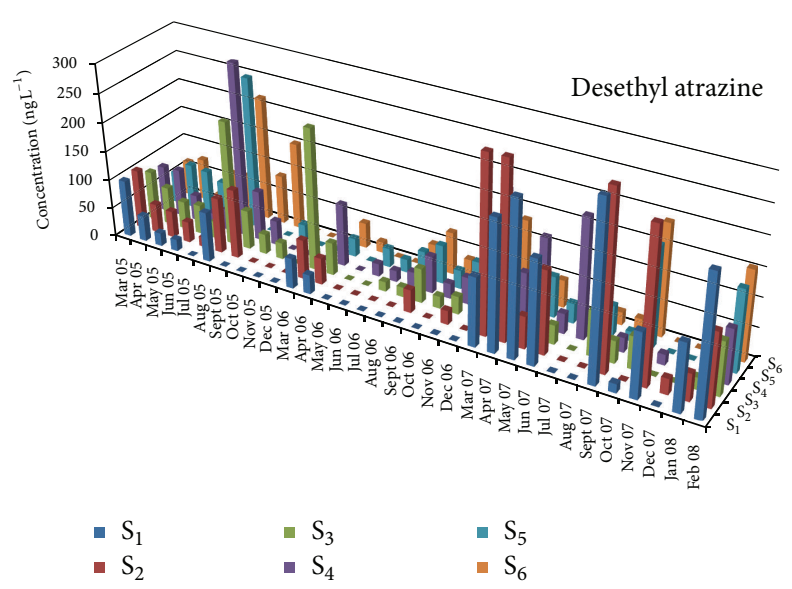

(c)

FIGURE 2: Temporal and spatial distribution of selected herbicide (atrazine (a), alachlor (b)) and metabolites (DEA (c)) concentrations during the sampling period (March 2005-February 2008) for the six sampling sites.

concentrations with significant differences $(P<0.05)$ among upper $\left(\mathrm{S}_{1}-\mathrm{S}_{3}\right)$ and lower $\left(\mathrm{S}_{4}-\mathrm{S}_{6}\right)$ sampling stations. Diazinon had the highest mean concentration $\left(\mathrm{S}_{5}: 26.3 \pm 3.48 \mathrm{ng} \mathrm{L}{ }^{-1}\right)$ and dimethoate the lowest $\left(\mathrm{S}_{1}: 2.29 \pm 0.55 \mathrm{ng} \mathrm{L}^{-1}\right)$.

3.1.2. Seasonal Variation. Tables 3(a) and 3(b) present the seasonal mean concentrations of the detected compounds in river water, for each year of the sampling period. In addition Table 4 displays the three-year seasonal mean concentrations of all compounds. An overview of the results shows a seasonal variation and higher mean values for spring and summer compared to fall and winter, although the differences are not significant for all compounds either when seasonal average for each year or three-year seasonal mean concentrations are considered. It should be noticed that the application period for the detected compounds in the area generally begins in mid-March and continues until mid-July. Therefore, it was expected to record the highest concentration levels in river water during the spring-summer period.

Maximum mean values were observed in spring for the majority of the detected pesticides (nine, twelve, and ten compounds for the years 2005, 2006, and 2007, respectively). In summer, the highest mean concentration was recorded for eight compounds (malaoxon, diazinon, fenthion, pirimiphos methyl, methidathion, DEA, alachlor, and trifluralin) in 2005, five compounds (alachlor, parathion methyl, dimethoate, fenthion, and methidathion) in 2006, and four compounds (atrazine, S-metolachlor, triadimefon, and pyrazophos) in 2007. The maximum mean concentrations in autumn were recorded for pyrazophos and chloropyrifos methyl in 2005, penconazole and dichlorvos in 2006 and trifluralin, alachlor, methidathion, and S-metolachlor in 2007. Dimethoate was the only pesticide that showed a highest mean concentration in winter of 2007.

Atrazine's mean concentration, in 2005, was statistically different in spring $\left(77.1 \pm 18.7 \mathrm{ng} \mathrm{L}^{-1}\right)$ in comparison with the other seasons. The same results were observed in the case of S-metolachlor (10.2 $\pm 1.26 \mathrm{ng} \mathrm{L}^{-1}$ in spring). In 2005, alachlor's mean concentration presented statistically significant difference in summer $\left(56.5 \pm 12.1 \mathrm{ng} \mathrm{L}^{-1}\right)$ in comparison with autumn and winter. DEA presented significant differences in concentration during the spring of the year 2007 with a maximum mean concentration of $129 \pm 21.9 \mathrm{ng} \mathrm{L}^{-1}$. 


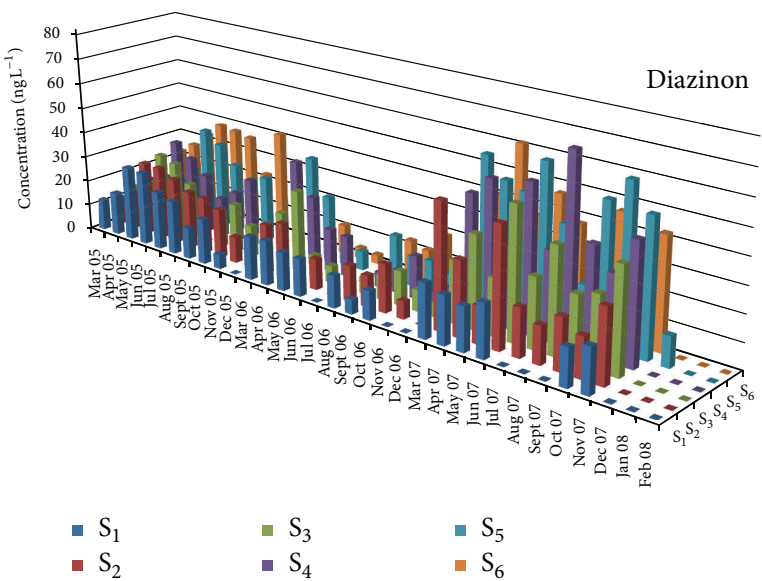

(a)

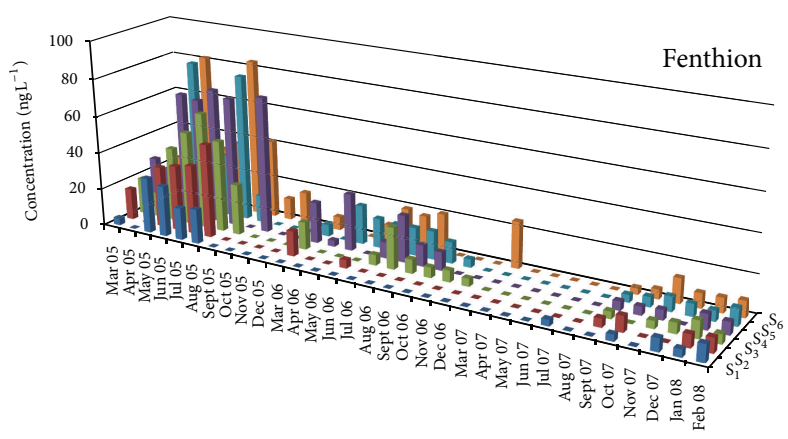

$=\mathrm{S}_{1} \quad \because \mathrm{S}_{3} \quad-\mathrm{S}_{5}$

(b)

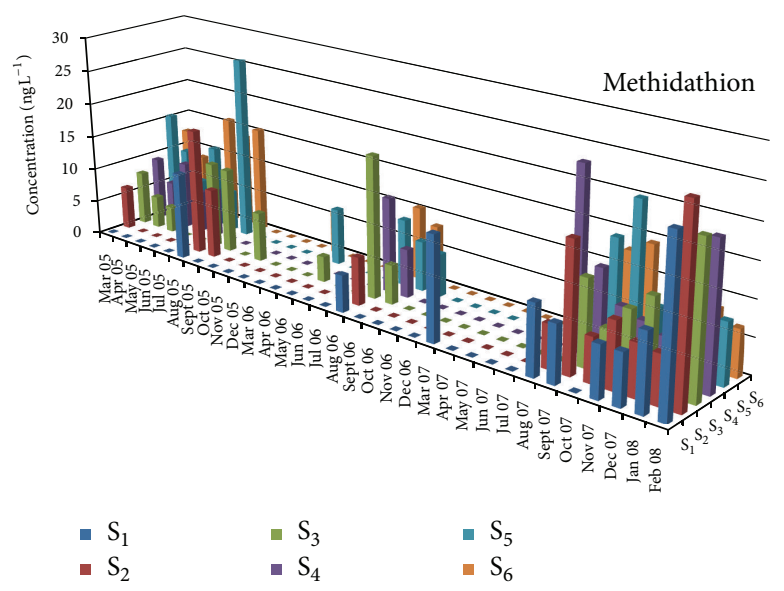

(c)

Figure 3: Temporal and spatial distribution of selected insecticide (diazinon (a), fenthion (b), and methidathion (c)) concentrations during the sampling period (March 2005-February 2008) for the six sampling sites.

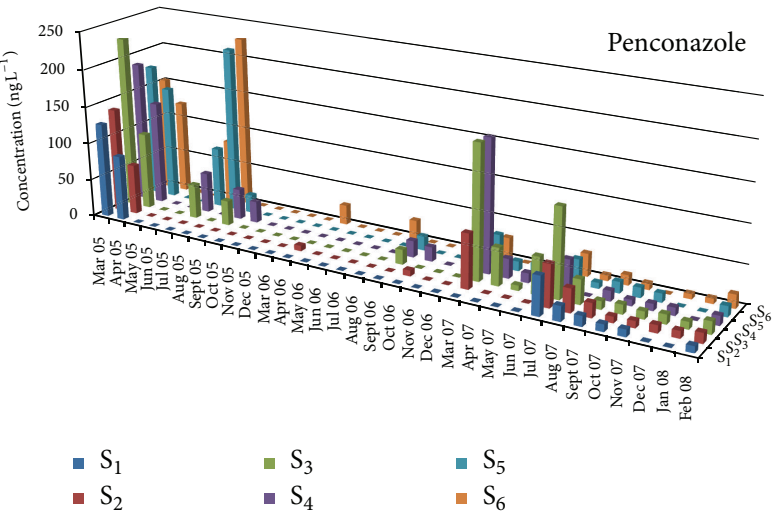

(a)

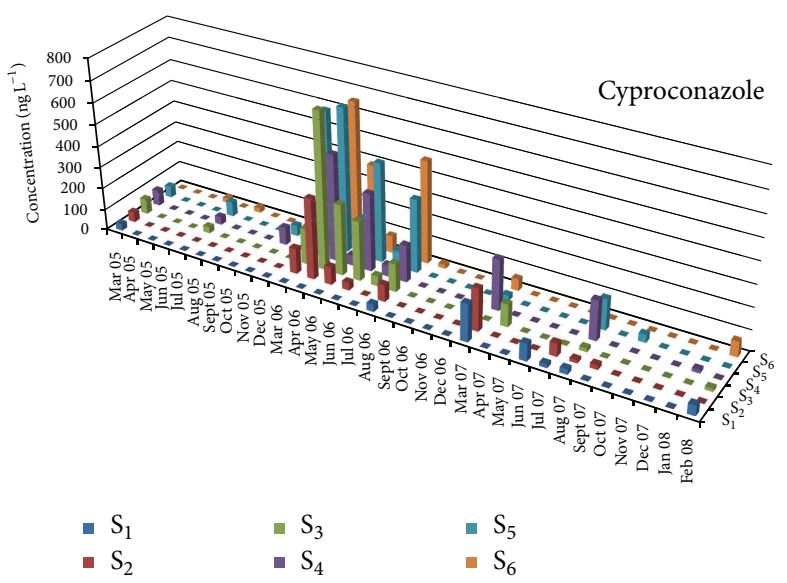

(b)

FIGURE 4: Temporal and spatial distribution of selected fungicide (penconazole (a) and cyproconazole (b)) concentrations during the sampling period (March 2005-February 2008) for the six sampling sites. 


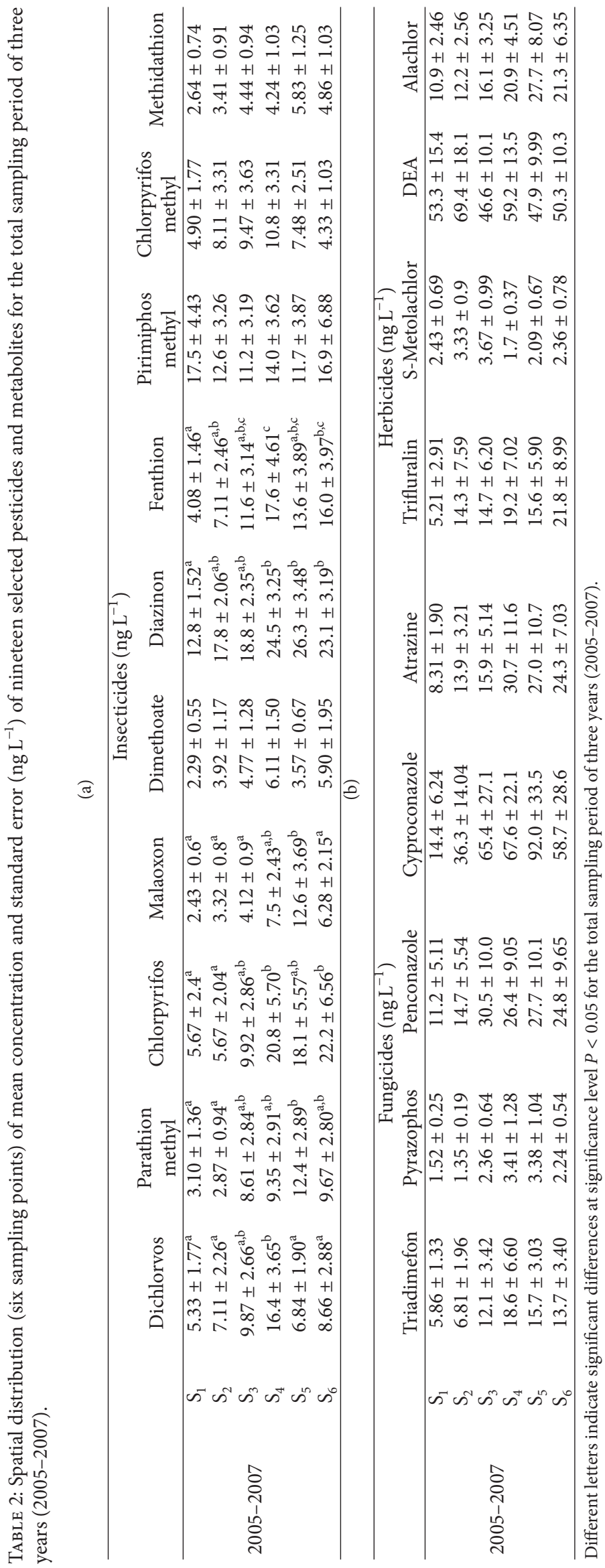




\section{章}

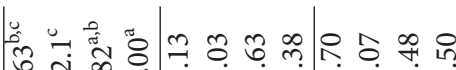

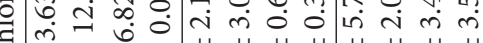

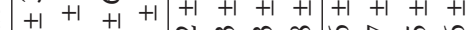

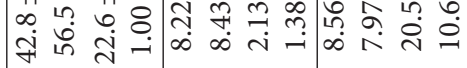

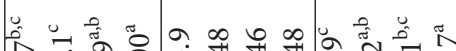
《约 הี $2+1+1+1+1+1+1+1+1+1+1$ तỉ

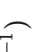

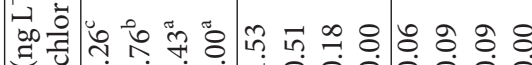

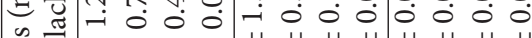

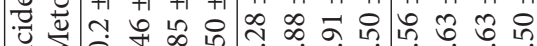

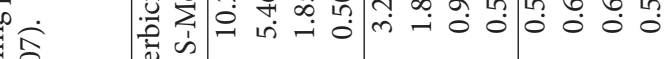

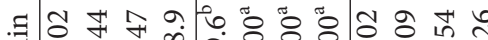

$\exists+1+1+1+1+1+1+1+1+1+1+1+1$

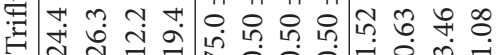

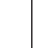

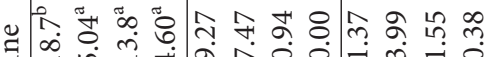

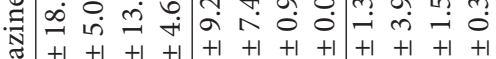

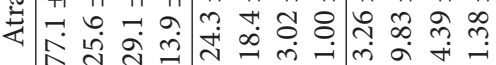

$\div$

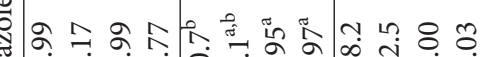

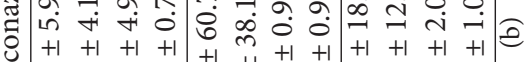

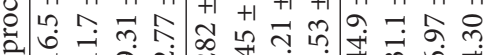

ㅎํㄹ

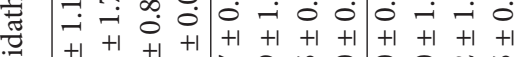

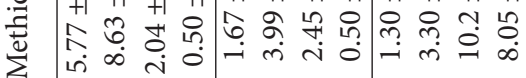

\% + +

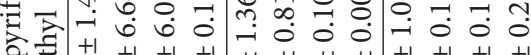

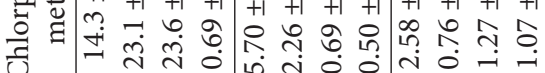

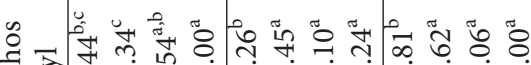
द्वे 年 $+1+1+1+1+1+1+1+1+1+1+1+1$

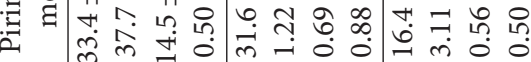

.

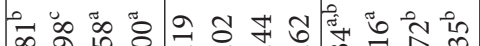
nं + + i $\begin{array}{lllllllllll}+1 & +1 & +1 & +1 & +1 & +1 & +1 & +1 & +1 & +1 & +1 \\ +1 & +1 & \end{array}$ 死 प.

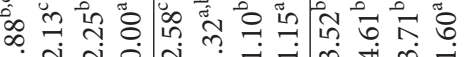
- 4 n

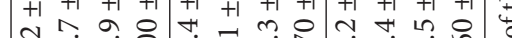
슐

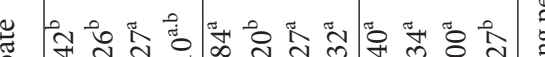

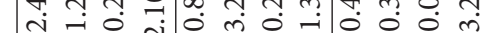

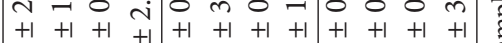
उु $\sigma$ के \& की

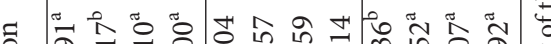
$2+1+1+1+1+1+1+1+1+1+1+1+1$

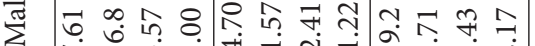
य

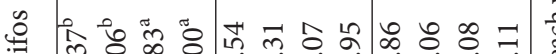
न लु a $+1+1+1+1+1+1+1+1+1+1+1+1$ 迹 경

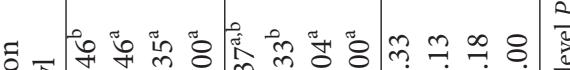

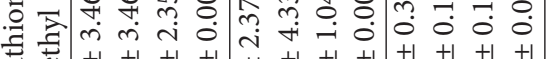
ש

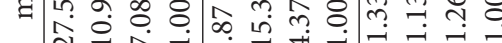

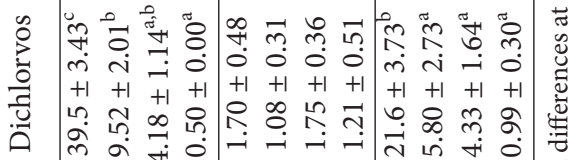




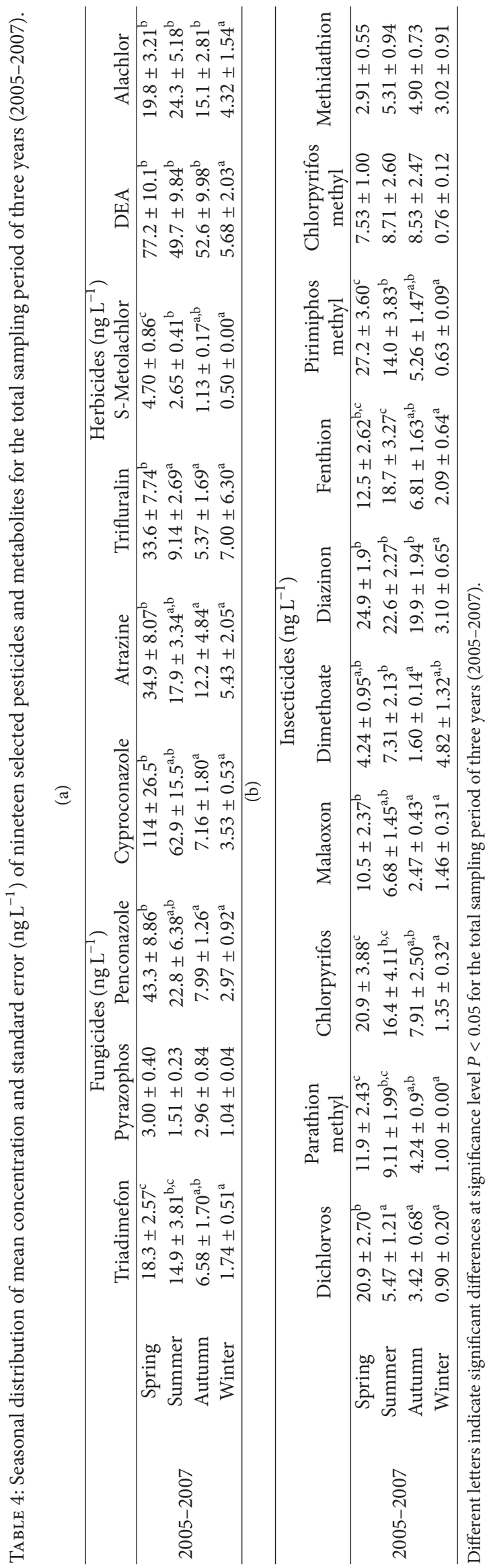


Finally, trifluralin showed the highest mean concentration, in spring of $2006\left(75.0 \pm 19.6 \mathrm{ng} \mathrm{L}^{-1}\right)$.

In the case of fungicides, mean concentrations of triadimefon $\left(35.6 \pm 3.66 \mathrm{ng} \mathrm{L}^{-1}\right)$ and penconazole (93.0 \pm $17.9 \mathrm{ng} \mathrm{L}^{-1}$ ) for the year 2005 were higher in spring and were significantly different in comparison with those recorded for the other seasons. In 2006, mean concentration of triadimefon $\left(11.1 \pm 2.40 \mathrm{ng} \mathrm{L}^{-1}\right)$ and cyproconazole $(282 \pm$ $60.7 \mathrm{ng} \mathrm{L}^{-1}$ ) was also significantly different in spring. No significant differences for fungicides concentrations were recorded for the year 2007.

Finally in the case of insecticides, in 2005, mean concentrations of dichlorvos and parathion methyl showed higher and significantly different concentrations in spring while malaoxon and fenthion presented higher and significantly different concentrations in summer. In the spring of 2006, mean concentrations of diazinon, pirimiphos methyl, and chlorpyrifos methyl were higher and significantly different in comparison with the other seasons while dimethoate showed significantly higher concentrations in summer. For the year 2007, dichlorvos, malaoxon, and pirimiphos methyl presented higher and significantly different mean concentrations in spring.

Three of the total four fungicides (triadimefon, penconazole, and cyproconazole) showed in spring significant difference for the whole three years of sampling (2005-2007) in relation to autumn and winter (Table 4). Nonsignificant differences among seasons were observed for pyrazophos which is probably linked to its withdrawal from the market.

Most of herbicides (atrazine, trifluralin, S-metolachlor, and DEA) showed significantly higher three-year mean concentrations in spring than for the other seasons (Table 4). Methidathion and chlorpyrifos methyl are the only insecticides that did not show statistically significant differences for any of the seasons during the total sampling period. The majority of the insecticides (dichlorvos, parathion methyl, chlorpyrifos, malaoxon, and pirimiphos methyl) showed higher mean concentrations in the spring compared with the other seasons. Dimethoate and fenthion showed statistically significant difference and the highest three-year mean concentrations in summer.

In conclusion, fourteen of the nineteen compounds studied showed significant differences of three-year mean concentration values in spring and summer compared with the other two seasons (Table 4). Statistical analysis of data for the whole period of three-year sampling displays the same image in spring and summer, which were the seasons that pesticides presented the highest concentrations, since this is the main period of their application (in March until midJuly).

Table 5 presents a statistical analysis of annual mean concentrations of the analytes for the three-year monitoring. The fungicides, triadimefon, penconazole, and pyrazophos, showed the highest mean concentrations in 2005 with significant difference $(P<0.05)$ compared to 2006 and 2007. On the contrary, cyproconazole annual mean maximum value was observed in 2006. It should be noted that the compounds triadimefon and pyrazophos were exclusively applied in tobacco cultivation, which was eliminated in 2006 in the area close to the river course. As a result significant reduction in their annual mean concentrations was noticed ever since and consequently those two pesticides can be used as representative markers of changing land use [34,35].

All the studied herbicides showed the highest mean concentration levels in 2005 with significant differences compared with 2006 and 2007, except for the metabolite desethyl atrazine (DEA) that showed the highest mean concentrations in 2007. Eight (dichlorvos, parathion methyl, chlorpyrifos, malaoxon, dimethoate, fenthion, pirimiphos methyl, and chlorpyrifos methyl) of the total ten insecticides had higher mean concentrations in 2005 with significant difference compared to 2006 or 2007. Only diazinon and methidathion showed the highest mean concentration in 2007 with significant difference in comparison with the other two sampling years and 2006, respectively.

Peak mean concentrations for twelve pesticides were observed in 2005 with a significant difference from the concentrations recorded for the other two years. Tobacco was the most important crop in Aitoloakarnania prefecture for decades with an area accounting $25 \%$ of total cultivated land. The abolition of the tobacco crop in 2006 resulted in a lower mean concentration recording of the majority of studied pesticides in river water, as 2006 was a year of fallow.

Many herbicides found in the present study in Acheloos River, such as alachlor, atrazine, S-metolachlor, trifluralin, and the metabolite deethylatrazine, as well as insecticides such as chlorpyrifos methyl, diazinon, and dimethoate, have been frequently detected in the past studies in the rivers of Greece $[9,29,36]$. Based on many previous studies [36-39], the pesticide levels in surface waters are related to the time, the way of their application, and their use in agricultural activities as well as to the physical-chemical properties of the organic compounds and of the soil and the frequency of rainfall. Important quantities of pesticides were guided from the field to the aquatic resources when the first runoffproducing rain occurred soon after application.

The highest concentrations of pesticides in surface waters surrounded by agricultural areas are dependant on meteorological and hydrological conditions. Water systems with relatively small drainage basins, such as in the case of Acheloos River, show increased pesticide concentrations with short periods of elevated concentrations, of about one month. On the other hand, lower pesticide concentration peaks were observed in autumn months after the early rainfalls following the dry summer period [9]. In winter and autumn, pesticides' mean concentration decreases considerably due to dilution effects caused by high rainfall during these seasons and the degradation that occurs after their application.

Atrazine was the most popular herbicide in Greeceespecially in the cultivation of tobacco until 2006-and it was withdrawn in September 11, 2004 with the last official use in September 10, 2005. Atrazine and its metabolites can persist in water and soil for decades. Jablonowski et al. have demonstrated the high persistence of atrazine and its metabolites in soil $[40,41]$. The accumulation of the parent compound in the soil may result in a long-term source of 


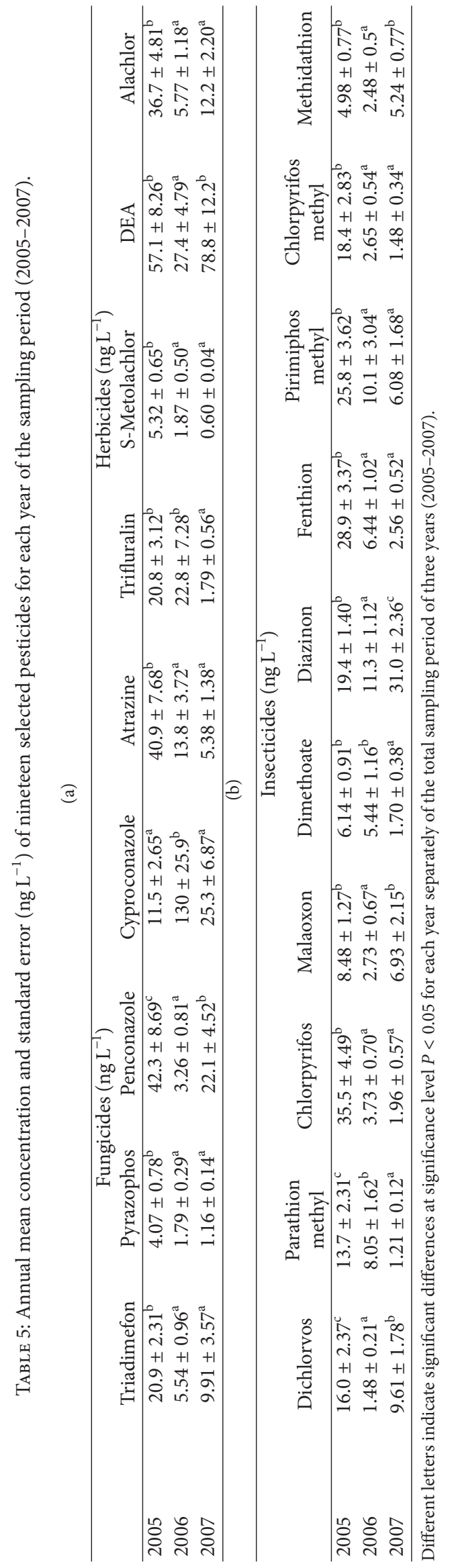


atrazine and its metabolites to ground water or surface waters [42].

To investigate the relative age of atrazine, the desethyl atrazine-to-atrazine ratio (DAR) was calculated. At first, soil microorganisms metabolize atrazine to DEA; thus, as long as atrazine remains in soil, metabolic activity continues and increasing DEA amounts were transported to surface and ground waters. DAR values greater than 1.0 are calculated for atrazine transport through the unsaturated zone, while DAR values much less than 1.0 are found when atrazine was transported off the field by surface runoff [43]. DAR values less than 0.05 were reported in runoff from agricultural areas soon after atrazine application [44] and DAR values between 0.5 and 0.7 after the atrazine application. Finally, high DAR values correspond to long periods after atrazine application in soils, while values $<0.5$ may suggest preferential flow in soils [45].

In our study, DAR values were quite high while most of the observed values were $>1$ due to the past uses of atrazine and the prolonged degradation of atrazine in soil and surface water. Garmouma et al. [46] have also reported DAR values higher than 1 for longer periods after atrazine application. During the sampling period of three years, DAR presented higher values in spring. This is in accordance with seasonal variation of triazines concentrations, which have a major input in spring after their application in crops, as reported in previous studies [47-49]. Additionally, water quantities discharging to Acheloos River due to run-off, increased also in spring. On the other hand, DAR values were lower in 2005 and increased in 2006 and the higher values were observed in 2007. Elimination of tobacco cultivation in 2006 minimized atrazine applications in the area leading thus to lower concentrations of atrazine and higher concentrations of DEA.

3.2. Risk Assessment. Environmental risk assessment was performed to evaluate negative impact of pesticides on the aquatic system of Acheloos River for the years 2005 and 2007. The results of calculated risk quotients for all the detected pesticides are presented in Table 6. In 2005, six pesticides (dichlorvos, chlorpyrifos, malaoxon, fenthion, pirimiphos methyl, and chlorpyrifos methyl) presented RQs higher than unit when using median MECs, while in 2007, only chlorpyrifos methyl showed RQs higher than unit. Pesticides mentioned above had the highest RQ values mainly due to their relatively high toxicity to aquatic organisms, hence producing quite low PNEC values. In addition, fungicides presented the lowest RQ values using both median and extreme MEC values for both sampling years (2005 and 2007). In general, highest RQs were calculated for insecticides, lower for herbicides, and the lowest for fungicides. This trend has been confirmed by recent studies of pesticide monitoring in drainage canals in Northeastern Greece [36]. Assessing the synergistic toxicity of pesticides in mixtures has been an enduring challenge for environmental health research and could be only determined via toxicity experiments. Based on the existing data on the combination effects from pesticide mixtures, the observed effects of pesticides from the same class are often additive
$[50,51]$. Even mixtures of herbicides with different modes of action generally show concentration additivity in their toxicity effects $[50,52]$. For this purpose, the detected pesticides are grouped in three subcategories based on their mode of action, that is, organophosphorus insecticides, herbicides, and azole fungicides and the cumulative risk assessment is determined. Cumulative risk quotients for fungicides were always lower than unit presenting acceptable risk, while maximum cumulative RQs for herbicides were always lower than 9.3 with a decreasing trend from 2005 to 2007. The same trend was observed also for insecticides which presented the highest cumulative risks (RQ values up to 115.5 in 2005). Taking into consideration that substantial synergistic effects have been observed for insecticide mixtures [53], unacceptable risks may be suggested for organophosphorus pesticides, especially for the year 2005.

The European Union Water Framework Directive (WFD) 2000/60/EC established a framework for community action in the field of water policy that aims at reducing progressively the emission of hazardous substances and achieving a good ecological status in European river basins by 2015. A number of pesticide compounds such as alachlor, atrazine, chlorpyrifos, diuron, isoproturon, simazine, and trifluralin are included in the list of 33 priority substances defined in Annex I of the Directive 2008/105/EC. The WFD has defined the concentrations of the priority substances in water to be below the Environmental Quality Standards (EQSs), the annual average (AA), and the maximum allowed concentration (MAC). The annual average end point has been established at a level providing protection against longterm effects while the maximum allowable concentration has been established taking into consideration the protection of the aquatic ecosystem against short-term exposure [32]. It should be noted that up to six pesticides (atrazine, simazine, alachlor, trifluralin, diazinon, and chlorpyrifos) included in the list of the 33 priority substances (Annex I of the 2008/105/EC Directive) have been detected in the water samples of Acheloos River. Only chlorpyrifos and diazinon annual average concentration (in 2005 and in 2007, respectively) was slightly higher than the annual average concentration proposed by EQS (Table 7). On the other hand, the recorded pesticides' maximum concentrations were lower than the maximum allowed concentrations posed by WFD (Table 7). Thus, pesticides' monitoring results showed a good compliance with WFD for the majority of them.

\section{Conclusions}

Seventeen pesticides belonging to various categories (insecticides, herbicides, and fungicides) and two metabolites, out of thirty target compounds monitored during a threeyear period (March 2005-February 2008), had detection frequencies greater than $10 \%$ in Acheloos River, one of the most important aquatic systems in Western Greece. The most frequently detected compounds were diazinon (78.6\%), alachlor (50\%), penconazole (43.2\%), and DEA (69.3\%) for insecticides, herbicides, fungicides, and metabolites categories, respectively. 
TABLE 6: Environmental risk of pesticides detected in Acheloos River as risk quotient (MEC/PNEC) based on median and maximum residue values for 2005 and 2007.

\begin{tabular}{|c|c|c|c|c|c|c|}
\hline \multirow{2}{*}{ Pesticide } & \multirow{2}{*}{$\operatorname{PNEC}\left(\mu \mathrm{g} \mathrm{L}^{-1}\right)$} & \multirow{2}{*}{ Assessment factor } & $\mathrm{RQ}_{\text {median }}$ & $\mathrm{RQ}_{\max }$ & $\mathrm{RQ}_{\text {median }}$ & $\mathrm{RQ}_{\max }$ \\
\hline & & & \multicolumn{2}{|c|}{2005} & \multicolumn{2}{|c|}{2007} \\
\hline Dichlorvos & 0.0038 & 50 & 2.21 & 17.47 & 0.53 & 12.63 \\
\hline Parathion methyl & 0.0073 & 1000 & 0.25 & 9.07 & 0.27 & 0.96 \\
\hline Triadimefon & 0.34 & 50 & 0.05 & 0.22 & 0.01 & 0.57 \\
\hline Chlorpyrifos & 0.014 & 10 & 1.71 & 7.23 & 0.14 & 2.41 \\
\hline S-Metolachlor & 15.6 & 50 & 0.0003 & 0.001 & 0.0001 & 0.0001 \\
\hline Malaoxon & 0.003 & 50 & 1.90 & 17.83 & 0.67 & 26.87 \\
\hline Pyrazophos & 0.0036 & 50 & 0.28 & 9.08 & 0.28 & 2.61 \\
\hline Dimethoate & 4 & 10 & 0.001 & 0.01 & 0.001 & 0.01 \\
\hline Diazinon & 0.056 & 10 & 0.36 & 0.73 & 0.53 & 1.26 \\
\hline Penconazole & 1.2 & 50 & 0.002 & 0.19 & 0.01 & 0.15 \\
\hline Fenthion & 0.0057 & 1000 & 3.33 & 14.75 & 0.18 & 4.33 \\
\hline Atrazine desethyl & 0.72 & 1000 & 0.06 & 0.44 & 0.05 & 0.44 \\
\hline Alachlor & 2 & 10 & 0.02 & 0.11 & 0.002 & 0.05 \\
\hline Cyproconazole & 2 & 10 & 0.002 & 0.04 & 0.002 & 0.12 \\
\hline Atrazine & 10 & 10 & 0.003 & 0.03 & 0.0002 & 0.01 \\
\hline Trifluralin & 0.5 & 10 & 0.04 & 0.23 & 0.01 & 0.04 \\
\hline Pirimiphos methyl & 0.0016 & 50 & 16.28 & 50.67 & 0.63 & 41.15 \\
\hline Chlorpyrifos methyl & 0.001 & 10 & 10.00 & 77.11 & 1.08 & 19.61 \\
\hline Methidathion & 0.0132 & 50 & 0.15 & 2.02 & 0.15 & 1.90 \\
\hline
\end{tabular}

TABLE 7: Compliance of detected concentrations with environmental quality standards (EQS) ( $\left.\mu \mathrm{g} \mathrm{L} \mathrm{L}^{-1}\right)$ established for the priority pesticides monitored in the present study.

\begin{tabular}{|c|c|c|c|c|c|c|c|c|}
\hline \multirow{3}{*}{ Pesticide } & \multirow{3}{*}{$\begin{array}{c}\text { AA-EQS } \\
\text { Inland waters }\end{array}$} & \multirow{3}{*}{$\begin{array}{c}\text { MAC-EQS } \\
\text { Inland waters }\end{array}$} & \multirow{2}{*}{\multicolumn{3}{|c|}{$\begin{array}{l}\text { AA-River } \\
\text { Acheloos }\end{array}$}} & \multirow{2}{*}{\multicolumn{3}{|c|}{$\begin{array}{c}\text { MAC-River } \\
\text { Acheloos }\end{array}$}} \\
\hline & & & & & & & & \\
\hline & & & 2005 & 2006 & 2007 & 2005 & 2006 & 2007 \\
\hline Alachlor & 0.3 & 0.7 & 0.037 & 0.006 & 0.012 & 0.213 & 0.039 & 0.098 \\
\hline Atrazine & 0.6 & 2 & 0.041 & 0.014 & 0.005 & 0.288 & 0.138 & 0.068 \\
\hline Chlorpyrifos & 0.03 & 0.1 & 0.035 & 0.004 & 0.002 & 0.101 & 0.024 & 0.034 \\
\hline Diazinon & 0.02 & - & 0.019 & 0.011 & 0.031 & 0.041 & 0.039 & 0.070 \\
\hline Simazine & 1 & 4 & \multicolumn{3}{|c|}{ Sporadically detections } & \multicolumn{3}{|c|}{ Sporadically detections } \\
\hline Trifluralin & 0.03 & Not applicable & 0.021 & 0.023 & 0.002 & 0.115 & 0.237 & 0.031 \\
\hline
\end{tabular}

The statistical analysis of the results, revealed that the spatial distribution of mean concentrations of the target compounds showed a general trend with greater values for the last three stations $\left(\mathrm{S}_{4}, \mathrm{~S}_{5}\right.$, and $\left.\mathrm{S}_{6}\right)$ than those located upstream $\left(S_{1}, S_{2}\right.$, and $\left.S_{3}\right)$. Seasonal variation showed in general higher mean concentrations for spring and summer compared to autumn and winter. The annual distribution of mean concentrations of pesticides was strongly affected by the elimination of tobacco cultivation in 2006. The desethyl atrazine-to-atrazine ratio (DAR) was found quite high due to the past uses of atrazine and the prolonged degradation of atrazine in soil and surface water. DAR values were lower in 2005, increased in 2006, and reached the highest values in 2007.

The environmental risk assessment of pesticide residues showed that six of the total nineteen compounds (dichlorvos, chlorpyrifos, malaoxon, fenthion, pirimiphos methyl, and chlorpyrifos methyl) presented RQs higher than unit in 2005 when using median MECs, while in 2007, only chlorpyrifos methyl showed RQs higher than unit. Fungicides presented the lowest RQ values using both median and extreme MEC values for both sampling years (2005 and 2007). Finally, the annual average (AA) and the maximum allowed concentration (MAC) of six pesticides (atrazine, simazine, alachlor, trifluralin, diazinon, and chlorpyrifos) included in the list of the 33 priority substances were in general (except chlorpyrifos for year 2005 and diazinon for year 2007) lower than the concentration levels of the Environmental Quality Standards (EQS) defined by Water Framework Directive 2000/60/EC.

\section{References}

[1] J. Gascón, J. S. Salau, A. Oubinã, and D. Barceló, "Monitoring of organonitrogen pesticides in the Ebro river. Preliminary loadings estimates," Analyst, vol. 123, no. 5, pp. 941-945, 1998. 
[2] T. A. Albanis, D. G. Hela, T. M. Sakellarides, and I. K. Konstantinou, "Monitoring of pesticide residues and their metabolites in surface and underground waters of Imathia (N. Greece) by means of solid-phase extraction disks and gas chromatography," Journal of Chromatography A, vol. 823, no. 1-2, pp. 59-71, 1998.

[3] R. P. Richards and D. B. Baker, "Pesticide concentration patterns in agricultural drainage networks in the Lake Erie basin," Environmental Toxicology and Chemistry, vol. 12, no. 1, pp. 1326, 1993.

[4] R. A. Leonard, "Movement of pesticides into surface waters," in Pesticides in the Soil Environment: Processes, Impacts and Modeling, H. H. Cheng, Ed., pp. 303-349, Soil Science Society of America, Madison, Wis, USA, 1990.

[5] S. J. Larson, P. D. Capel, D. A. Goolsby, S. D. Zaugg, and M. W. Sandstrom, "Relations between pesticide use and riverine flux in the Mississippi river basin," Chemosphere, vol. 31, no. 5, pp. 3305-3321, 1995.

[6] T. A. Albanis, D. G. Hela, D. A. Lambropoulou, and V. A. Sakkas, "Gas chromatographic-mass spectrometric methodology using solid-phase microextraction for the multiresidue determination of pesticides in surface waters," International Journal of Environmental Analytical Chemistry, vol. 84, no. 14-15, pp. 1079-1092, 2004.

[7] D. A. Lambropoulou, V. A. Sakkas, D. G. Hela, and T. A. Albanis, "Application of solid-phase microextraction in the monitoring of priority pesticides in the Kalamas river (N.W. Greece)," Journal of Chromatography A, vol. 963, no. 1-2, pp. 107-116, 2002.

[8] R. J. C. A. Steen, J. Van der Vaart, M. Hiep, B. Van Hattum, W. P. Cofino, and U. A. T. Brinkman, "Gross fluxes and estuarine behaviour of pesticides in the scheldt estuary (1995-1997)," Environmental Pollution, vol. 115, no. 1, pp. 65-79, 2001.

[9] I. K. Konstantinou, D. G. Hela, and T. A. Albanis, "The status of pesticide pollution in surface waters (rivers and lakes) of Greece. Part I. Review on occurrence and levels," Environmental Pollution, vol. 141, no. 3, pp. 555-570, 2006.

[10] T. A. Albanis, T. G. Danis, D. Voutsa, and T. Kouimtzis, "Evaluation of chemical parameters in Aliakmon river northern Greece. Part III. Pesticides," Journal of Environmental Science and Health A, vol. 30, no. 9, pp. 1945-1956, 1995.

[11] T. A. Albanis, T. G. Danis, and M. K. Kourgia, “Transportation of pesticides in estuaries of the axios, Loudias and Aliakmon rivers (Thermaikos Gulf), Greece," Science of the Total Environment, vol. 156, no. 1, pp. 11-22, 1994.

[12] E. Papadopoulou-Mourkidou, D. G. Karpouzas, J. Patsias et al., "The potential of pesticides to contaminate the groundwater resources of the Axios river basin in Macedonia, Northern Greece. Part I. Monitoring study in the north part of the basin," Science of the Total Environment, vol. 321, no. 1-3, pp. 127-146, 2004.

[13] G. E. Miliadis and P. T. Malatou, "Monitoring of the pesticide levels in natural waters of Greece," Bulletin of Environmental Contamination and Toxicology, vol. 59, no. 6, pp. 917-923, 1997.

[14] T. A. Albanis, P. J. Pomonis, and Th. A. Sdoukos, "Organophosphorous and carbamates pesticide residues in the aquatic system of Ioannina basin and Kalamas river (Greece)," Chemosphere, vol. 15, no. 8, pp. 1023-1034, 1986.

[15] D. Tsipi and A. Hiskia, "Organochlorine pesticides and triazines in the drinking water of Athens," Bulletin of Environmental Contamination and Toxicology, vol. 57, no. 2, pp. 250-257, 1996.

[16] M. O. Angelidis, P. G. Markantonatos, N. C. Bacalis, and T. A. Albanis, "Seasonal fluctuations of nutrients and pesticides in the basin of Evrotas river, Greece," Journal of Environmental Science and Health A, vol. 31, no. 2, pp. 387-410, 1996.

[17] S. K. Golfinopoulos, A. D. Nikolaou, M. N. Kostopoulou, N. K. Xilourgidis, M. C. Vagi, and D. T. Lekkas, "Organochlorine pesticides in the surface waters of northern Greece," Chemosphere, vol. 50, no. 4, pp. 507-516, 2003.

[18] N. T. Skoulikidis, "Hydrochemical character and spatiotemporal variations in a heavily modified river of western Greece," Environmental Geology, vol. 43, no. 7, pp. 814-824, 2003.

[19] V. Ovezikoglou, M. Ladakis, M. Dassenakis, and M. Skoullos, "Nitrogen, phosphorus and organic carbon in main rivers of the western Greece," Global Nest, vol. 5, pp. 147-156, 2003.

[20] M. Dassenakis, M. Scoullos, and A. Gaitis, "Trace metals transport and behaviour in the Mediterranean estuary of Acheloos River," Marine Pollution Bulletin, vol. 34, no. 2, pp. 103-111, 1997.

[21] I. Hatzianestis and E. Sklivagou, "Hydrocarbon contamination in sediments from five major Greek estuaries," Environmental Science and Pollution Research, pp. 60-61, 32002.

[22] A. A. Psilovikos, "Optimization models in groundwater management, based on linear and mixed integer programming. An application to a Greek hydrogeological basin," Physics and Chemistry of the Earth B, vol. 24, no. 1-2, pp. 139-144, 1999.

[23] N. Th. Fourniotis, "A proposal for impact evaluation of the diversion of the Acheloos River, on the acheloos estuary in western Greece," International Journal of Engineering Science and Technology, vol. 4, pp. 1793-1802, 2012.

[24] N. Stamatis and I. Konstantinou, "Occurrence and removalof emerging pharmaceutical, personal care compoundsand caffeine tracer in municipal sewage treatment plant in western Greece," Journal of Environmental Science and Health B, vol. 48, pp. 800-813, 2013.

[25] N. Stamatis, D. Hela, and I. Konstantinou, "Occurrence and removal of fungicides in municipal sewage treatment plant," Journal of Hazardous Materials, vol. 175, no. 1-3, pp. 829-835, 2010.

[26] N. Stamatis, I. Konstantinou, and D. Hela, "Pesticide inputs from the sewage treatment plant of agrinio to river acheloos, western Greece: occurrence and removal," Water Science and Technology, vol. 62, no. 5, pp. 1098-1105, 2010.

[27] European Commission, Technical Guidance Document in Support of Commission Directive 93/67/EEC on Risk Assessment for New Notified Substances and Commission Regulation (EC) No 1488/94 on Risk Assessment for Existing Substances, Part II. Brussels, Belgium, 2003.

[28] I. Konstantinou, D. Hela, D. Lambropoulou, and T. AlbanisL, in Analysis of Pesticides in Food and Environmental Samples, J. Tadeo, Ed., CRC Press, 2008.

[29] Z. Vryzas, G. Vassiliou, C. Alexoudis, and E. PapadopoulouMourkidou, "Spatial and temporal distribution of pesticide residues in surface waters in northeastern Greece," Water Research, vol. 43, no. 1, pp. 1-10, 2009.

[30] Pesticide Properties database (PPDB), Agriculture \& Environment Research Unit (AERU), University of Hertfordshire, http://sitem.herts.ac.uk/aeru/footprint/en/index.htm.

[31] http://www.pesticideinfo.org/.

[32] A. A. Thomatou, I. Zacharias, D. Hela, and I. Konstantinou, "Determination and risk assessment of pesticide residues in lake Amvrakia (W. Greece) after agricultural land use changes in the lake's drainage basin," International Journal of Environmental Analytical Chemistry, vol. 93, no. 7, pp. 780-799, 2013. 
[33] M. D. Hernando, M. Mezcua, A. R. Fernández-Alba, and D. Barceló, "Environmental risk assessment of pharmaceutical residues in wastewater effluents, surface waters and sediments," Talanta, vol. 69, no. 2, pp. 334-342, 2006.

[34] K. E. Banks, D. H. Hunter, and D. J. Wachal, "Chlorpyrifos in surface waters before and after a federally mandated ban," Environment International, vol. 31, no. 3, pp. 351-356, 2005.

[35] K. E. Banks, D. H. Hunter, and D. J. Wachal, "Diazinon in surface waters before and after a federally-mandated ban," Science of the Total Environment, vol. 350, no. 1-3, pp. 86-93, 2005.

[36] Z. Vryzas, C. Alexoudis, G. Vassiliou, K. Galanis, and E. Papadopoulou-Mourkidou, "Determination and aquatic risk assessment of pesticide residues in riparian drainage canals in northeastern Greece," Ecotoxicology and Environmental Safety, vol. 74, no. 2, pp. 174-181, 2011.

[37] A. Hildebrandt, M. Guillamón, S. Lacorte, R. Tauler, and D. Barceló, "Impact of pesticides used in agriculture and vineyards to surface and groundwater quality (North Spain)," Water Research, vol. 42, no. 13, pp. 3315-3326, 2008.

[38] K. M. A. Holvoet, P. Seuntjens, and P. A. Vanrolleghem, "Monitoring and modeling pesticide fate in surface waters at the catchment scale," Ecological Modelling, vol. 209, no. 1, pp. 53-64, 2007.

[39] V. Triantafyllidis, D. Hela, P. Dimopoulos, and T. Albanis, "Imidacloprid losses in surface runoff from plots cultivated with tobacco," International Journal of Environmental Analytical Chemistry, vol. 86, no. 3-4, pp. 185-194, 2006.

[40] N. D. Jablonowski, S. Köppchen, D. Hofmann, A. Schäffer, and P. Burauel, "Persistence of 14C-labeled atrazine and its residues in a field lysimeter soil after 22 years," Environmental Pollution, vol. 157, no. 7, pp. 2126-2131, 2009.

[41] N. D. Jablonowski, G. Hamacher, R. Martinazzo et al., "Metabolism and persistence of atrazine in several field soils with different atrazine application histories," Journal of Agricultural and Food Chemistry, vol. 58, no. 24, pp. 12869-12877, 2010.

[42] N. D. Jablonowski, A. Schäffer, and P. Burauel, "Still present after all these years: persistence plus potential toxicity raise questions about the use of atrazine," Environmental Science and Pollution Research, vol. 18, no. 2, pp. 328-331, 2011.

[43] C. D. Adams and E. M. Thurman, "Formation and transport of deethylatrazine in the soil and vadose zone," Journal of Environmental Quality, vol. 20, no. 3, pp. 540-547, 1991.

[44] E. M. Thurman, M. T. Meyer, M. S. Mills, L. R. Zimmerman, C. A. Perry, and D. A. Goolsby, "Formation and transport of deethylatrazine and deisopropylatrazine in surface water," Environmental Science Technology, vol. 28, no. 13, pp. 2267-2277, 1994.

[45] L. Ma and H. M. Selim, "Atrazine retention and transport in soils," Reviews of Environmental Contamination and Toxicology, vol. 145, pp. 129-173, 1996.

[46] M. Garmouma, M. J. Teil, M. Blanchard, and M. Chevreuil, "Spatial and temporal variations of herbicide (triazines and phenylureas) concentrations in the catchment basin of the Marne river (France)," Science of the Total Environment, vol. 224, no. 1-3, pp. 93-107, 1998.

[47] M. J. Cerejeira, P. Viana, S. Batista et al., "Pesticides in Portuguese surface and ground waters," Water Research, vol. 37, no. 5, pp. 1055-1063, 2003.

[48] J. Quintana, I. Martí, and F. Ventura, "Monitoring of pesticides in drinking and related waters in NE Spain with a multiresidue
SPE-GC-MS method including an estimation of the uncertainty of the analytical results," Journal of Chromatography A, vol. 938, no. 1-2, pp. 3-13, 2001.

[49] R. Carabias-Martínez, E. Rodríguez-Gonzalo, M. E. FernándezLaespada, L. Calvo-Seronero, and F. J. Sánchez-San Román, "Evolution over time of the agricultural pollution of waters in an area of Salamanca and Zamora (Spain)," Water Research, vol. 37, no. 4, pp. 928-938, 2003.

[50] M. Faust, R. Altenburger, T. Backhaus et al., "Joint algal toxicity of 16 dissimilarly acting chemicals is predictable by the concept of independent action," Aquatic Toxicology, vol. 63, no. 1, pp. 4363, 2003.

[51] B. I. Escher and J. L. M. Hermens, "Modes of action in ecotoxicology: their role in body burdens, species sensitivity, QSARs, and mixture effects," Environmental Science and Technology, vol. 36, no. 20, pp. 4201-4217, 2002.

[52] T. K. George and K. Liber, "Laboratory investigation of the toxicity and interaction of pesticide mixtures in Daphinia magna," Archives of Environmental Contamination and Toxicology, vol. 52, no. 1, pp. 64-72, 2007.

[53] J. W. Deneer, "Toxicity of mixtures of pesticides in aquatic systems," Pest Management Science, vol. 56, pp. 516-520, 2000. 

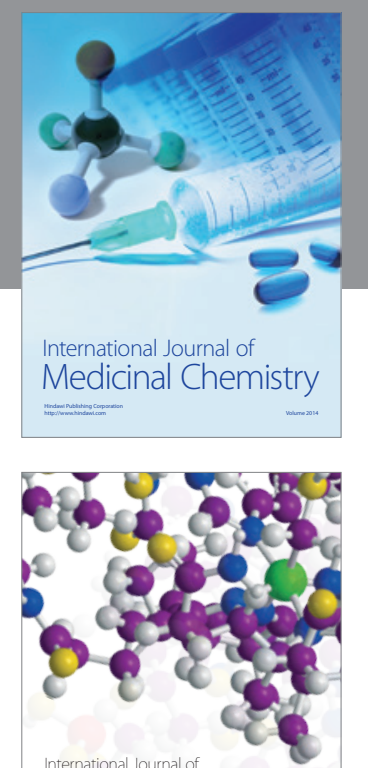

\section{Carbohydrate} Chemistry

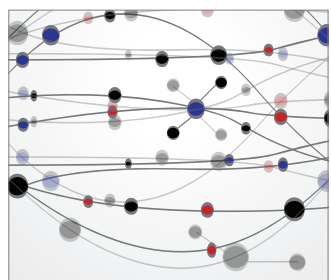

The Scientific World Journal
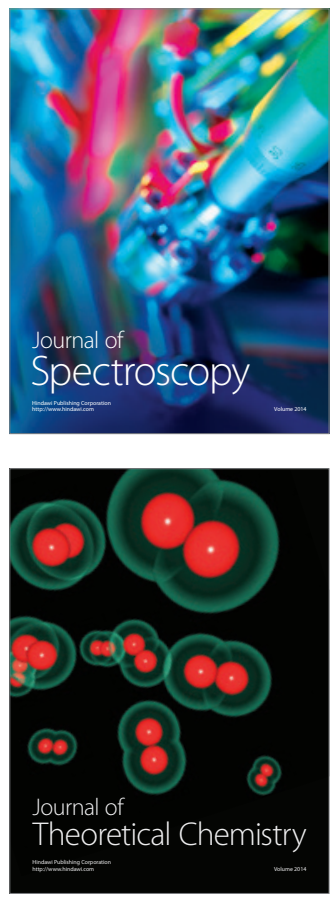
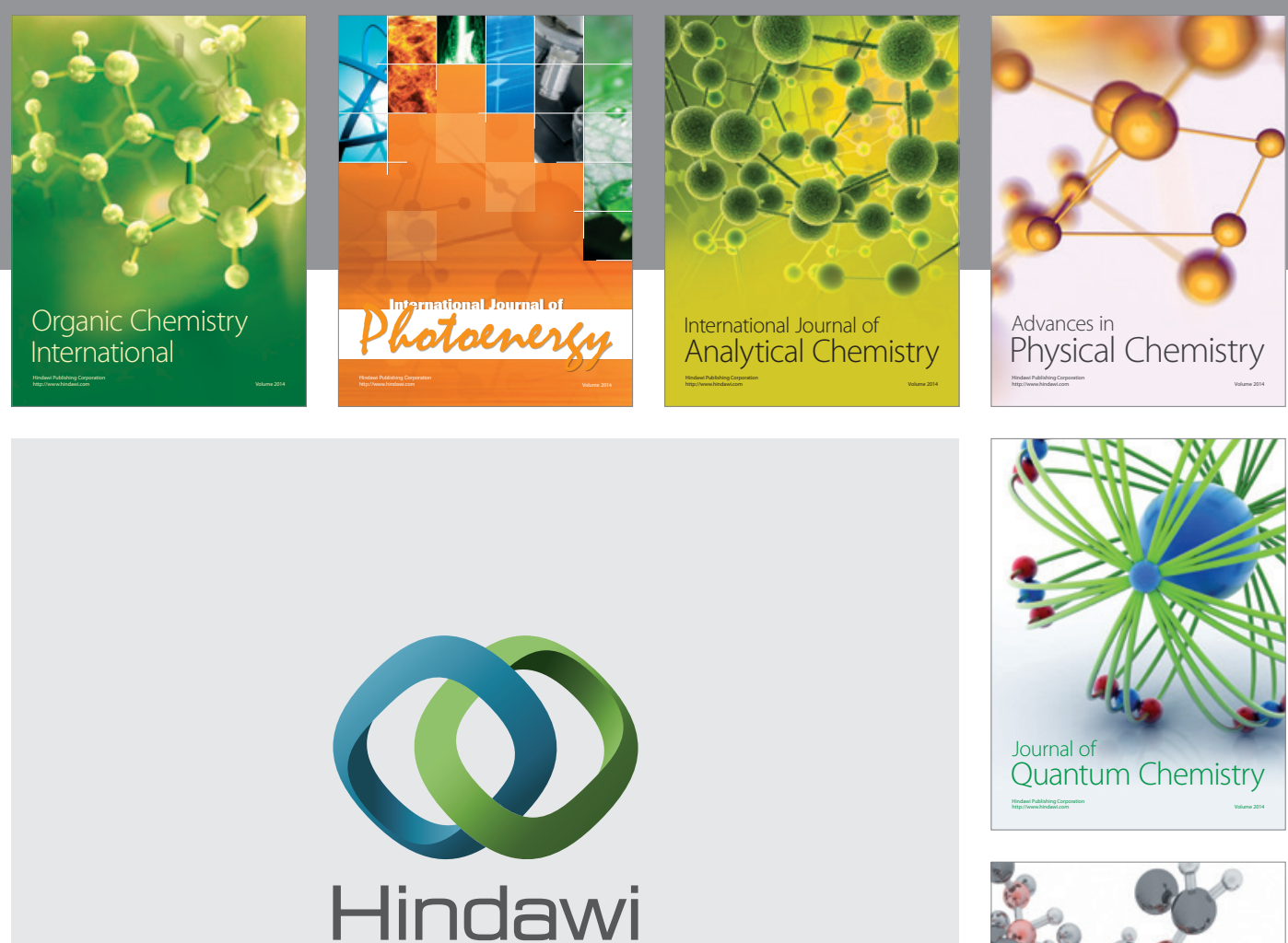

Submit your manuscripts at

http://www.hindawi.com

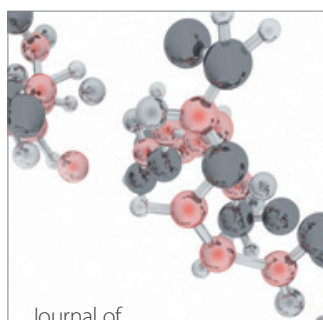

Analytical Methods

in Chemistry

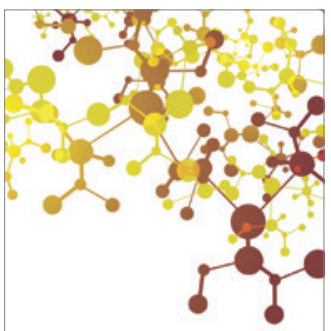

Journal of

Applied Chemistry

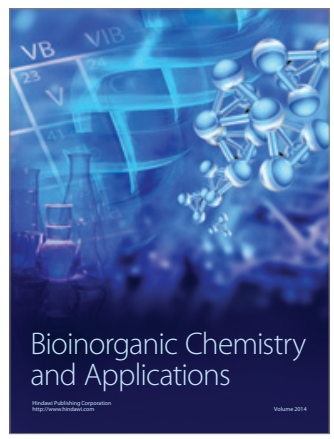

Inorganic Chemistry
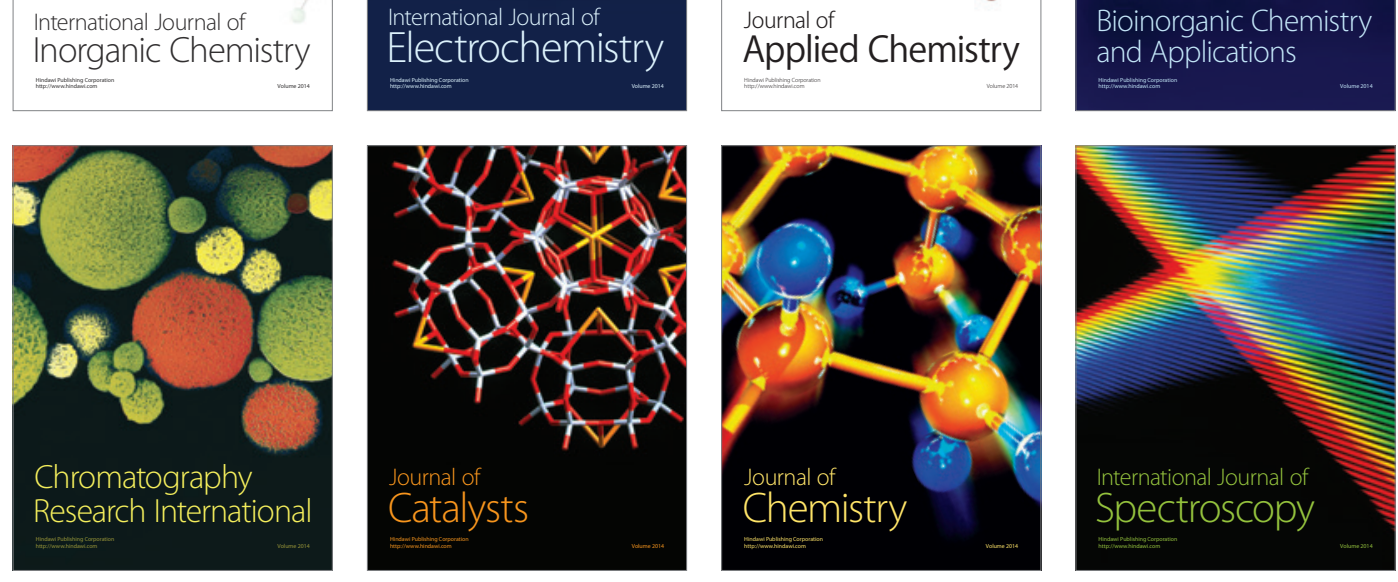